\title{
LINCOLN, SLAVERY, AND RACE IN CIVIL WAR NEW JERSEY: THE DOCUMENTARY EVIDENCE AND TREATMENTS IN FILM
}

\author{
BY LARRY A. GREENE
}

"Struggle without End" is an appropriate title for a war that took more American lives than all other American wars combined and a conflict that both sides expected to be over in a matter of months. Recent recalibrations have increased the death toll from 620,000 to nearly 750,000 . The then apparent unending nature of the war and its horrific casualties gave it an appearance of a war without end. But the war came to an end with the emancipation of four million slaves, the nation reunited, and a president whose stewardship of America through the most tumultuous four-and-one-half years of its young history marked him as one of America's greatest presidents. ${ }^{1}$

Certainly, this is the view of Lincoln that emerges in Steven Spielberg's recent movie, Lincoln (2012). It is a view that is difficult to disagree with, yet is irritatingly incomplete. The enduring legacy of Lincoln as the consummate politician, one of our greatest wartime presidents with a keen untutored military acumen and a humanitarian sensibility earning him the appellation, the "great emancipator," are all perceptions of Lincoln foregrounded in the film. Yet, what is missing from the film is Lincoln's ambivalence on the issue of racial equality, his inability to envision America as a multiracial democracy even well into the war, and his early reticence to support emancipation despite his eventual issuance of the Emancipation Proclamation. In not addressing these issues, the film thereby fails to explore Lincoln's capacity for transformative growth away from some of these early restrictive and conservative views. In short, Lincoln's conservatism and yet his capacity for growth are also that of the nation, the North, and New Jersey.

Two other films released just before and after Lincoln in 2012 and 2013 raise important questions concerning this turbulent era. Directors Steve McQueen's 12 Years a Slave (2013) and Quentin 
Tarantino's Django Unchained (2012) confront not only the physical oppression of slavery, but equally important the psychological impact of bondage upon the enslaved and the enslaver. Slave narratives of the antebellum era usually describe an escape from slavery to freedom, whereas Northup's narrative is unusual in describing the reverse route from freedom to slavery. It is this loss of freedom for a hard-working seemingly middle-class black free man that makes his story so compelling and yet so attractive to white middle class and black audiences alike. Django's postCivil War quest to find his beloved and enslaved wife necessitates gunning down slave traders and slave owners in the process. Despite Django's Sergio Leone's "Spaghetti Western" characteristics and absence of nuance, both films show the brutality of slavery and the psychologically desensitizing impact of slavery on owners and subsequently their capacity for dehumanization of slaves and themselves in the process. While 12 Years a Slave paints the Northern life of Solomon Northup in somewhat idyllic colors, the lives of most Northern free blacks were by no means so prosperous, middle class, or as respected by their white Northern fellow citizens as evidenced by the plight of blacks in New Jersey and other Northern free states.

On the Northern Civil War home front and in the state of New Jersey, the most pressing concern and glaring political issue for Lincoln, aside from the continuation of the war and the elusive decisive Union victory, was the acrimonious debate over emancipation. The Spielberg film is not a biopic of Lincoln's life or even presidency as were past Hollywood renderings of Lincoln, but rather an interpretation of that brief period near the end of the Civil War and Lincoln's death when he lobbied, coerced, and distributed patronage to achieve congressional passage of the Thirteenth Amendment thus reinforcing and enshrining the 1863 emancipation in the Constitution. PBS journalist Tavis Smiley in an interview with Marlow Stern in The Daily Beast, mused on the shortcoming of the Spielberg film:

It's a wonderful film, but it puts forth the proposition that Abraham Lincoln was always on the right side of the slavery question, and he wasn't. And there is not even a passing reference to Frederick Douglass in the film. Anyone who knows history knows it was Douglass talking to Lincoln repeatedly that helped get Lincoln 
on the right side of the slavery question and stiffen Lincoln's spine. So when people see these films, they take it as history. ${ }^{2}$

Douglass exerted pressure on Lincoln as did other black and white abolitionists to issue the proclamation. Although a valuable historical artistic piece of cinema craftsmanship educating the public about Civil War times, Lincoln does not adequately emphasize the current view among historians that the proclamation and even the Thirteenth Amendment should be viewed within the context of an emancipatory process. The process involved a number of factors. During the pre-war and war years there was the abolitionist influence on the public mind. In the war years prior to the Emancipation Proclamation there was the actual "self-emancipation" of slaves fleeing to Union lines where some Union generals offered freedom or sanctuary to fleeing slaves By 1862/1863 Lincoln also came to view the emancipation as something that would help the Union cause militarily.

Django garnered its share of criticism from fellow director Spike Lee and social critic Tavis Smiley while earning praise from film critic Frank Rich. Smiley charged Tarantino with making a "spoof about slavery" reducing black suffering and transcendence of slavery to "revenge and retribution" noting "black people have learned to love America in spite of not because of," injustice. ${ }^{3}$ However, the desire for revenge and retribution is human. In the post-emancipation South, black dreams of advancement and survival were based on the desire for land, the vote, and education which would hopefully lead to equal citizenship and equality of opportunity and eventually of condition. In so many ways this would constitute the sweetest revenge for reparations in the form of land and citizenship were far more important than actual physical retribution. Yet it is these hopes of the emancipated slaves that promoted Southern fear of a multiracial non-slave South and significant Northern white fears of black inundation by a migratory newly emancipated slave population during the Civil War and Reconstruction years. These fears drove Northern Democratic electoral campaigns throughout the 1850s, the Civil War era, and even the Reconstruction years as they continually played the "race card" often to their electoral advantage. ${ }^{4}$ In many ways, New Jersey and Northern politics during this time was not so much about black "revenge and retribution," but about the exploitation of white fears 
and orchestrated backlash to gain political advantage. Frank Rich in a New York Magazine review observed that as the movie Lincoln "portrays the politics we wish we had, so Django forces you to think about the unfinished business that keeps us from getting there just yet. ${ }^{\prime \prime}$ Yet in the quest to portray slavery's brutality and the African American need for justice and retribution, the realistic goals of the African American masses for economic justice, security, and American citizenship are lost in a plot of juvenile machismo.

An accomplishment of the Lincoln film is a revelation to the general public that even two years after the Emancipation Proclamation, there were significant elements in Congress who opposed the Thirteenth Amendment, who were unhappy with emancipation, and who were certainly not in favor of black citizenship. This insight into the racial attitudes of Northern congressional delegations illuminates the difficulties that Lincoln

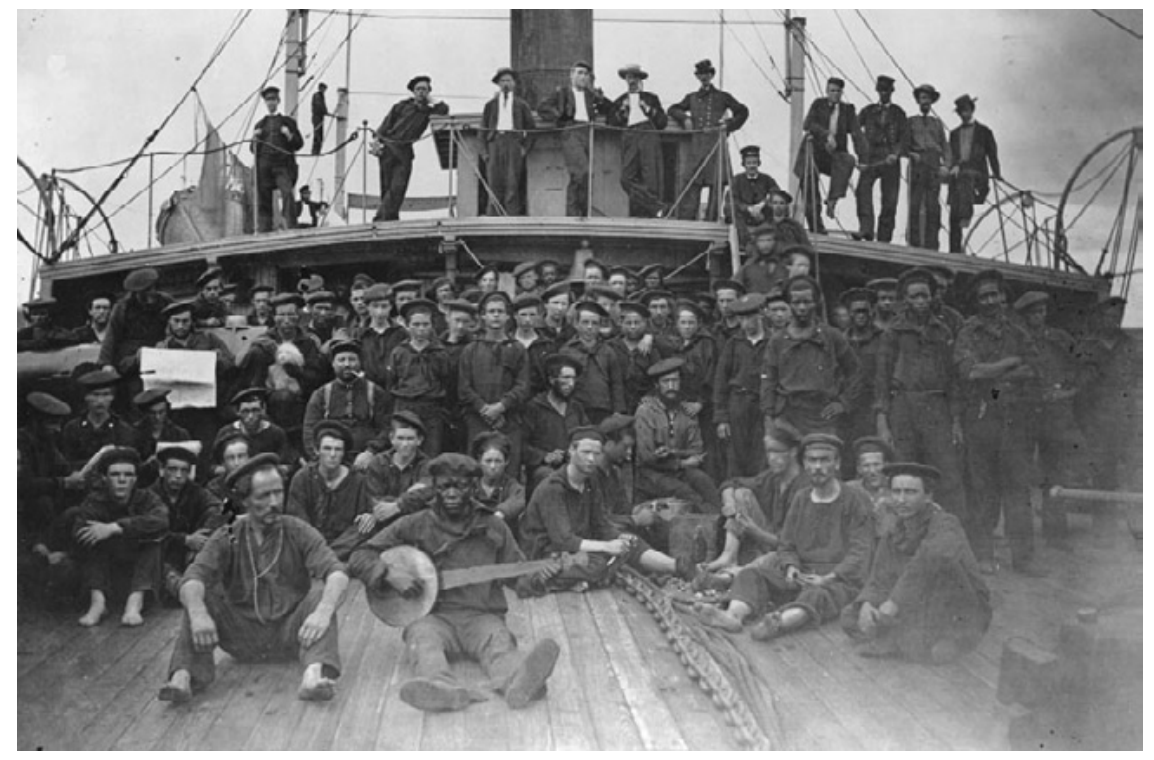

USS Hunchback

Photograph of the officers and crew, of which about one fifth are African American, aboard the USS Hunchback, ca. 1864-1865.

Naval Historical Foundation, photograph no. NH 59430.

had in Northern states like New Jersey throughout the war and even into the Reconstruction era. Lincoln had a remarkable transformation in his feelings about abolition and the place of black people in society. He evolved from being a theoretical 
abolitionist and supporter of black colonization outside of America, to an opponent of slavery expansionism, to the emancipator of Southern slaves, and finally to someone who tentatively and publicly contemplated black voting rights just three nights before his assassination. In January 1863, several years into the Civil War, he issued the Emancipation Proclamation expanding the Union cause from preservation of the Union to include emancipation and opening the ranks of the Union army to black enlistment. When the war ended, $10 \%$ of the Union Army was black as some 186,000 freedmen flocked to the American flag voting with their feet and reflecting their role in "self-emancipation." In his last public speech from the balcony of the White House on April 11,1865, Lincoln publicly contemplated the vote for educated freedmen and black Union army veterans which pushed the debate over black citizenship and equality into the national political arena. In the audience was John Wilkes Booth, who must have found this speech as further evidence of Union depravity on the race issue and of Northern desire to punish the South, both of which he felt could only be alleviated by the assassination of Lincoln. ${ }^{6}$ While the answer for Booth and other Southern extremists was presidential assassination, for most Southerners the answer lay in unyielding opposition to "Radical Republican" reconstruction of the South through the use of the Democratic Party coupled with the support of paramilitary violence by the Ku Klux Klan, White Leagues, Rifle Clubs, and other assorted white supremacist organizations especially around the time of elections. ${ }^{\text {? }}$

The complex transformation of Lincoln by the end of the war is best explored in Eric Foner's Pulitzer-winning biography of Lincoln, The Fiery Trial, and the excellent study of emancipation as a historical process by James Oakes, Freedom National. ${ }^{8} \mathrm{New}$ Jersey public opinion at war's end was equally complex and substantially varied on racial issues from black migration North to black citizenship and voting rights in within the state and towards the South. New Jersey's soldiers came home victorious from the battlefields across the nation, but just what they had been fighting for was still to be determined. True, the great goal of the war, preservation of the United States of America had been achieved at a tremendous cost in lives with Northern casualties nearly five times the nation's casualties in the Vietnam War, but most Jerseyans would deem the sacrifice worth it. Even those objecting to Lincoln's suspension of habeas corpus and the Emancipation 
Proclamation would deem the war necessary and celebrate the victorious preservation of the Union of States. The second mid-war presidentially-proclaimed goal of Emancipation was still debatable for many of the state's citizens and Democratic Party politicians. Vague statements and allusions from the president and a few Congressional Republicans about black citizenship and/or land reallocation from the Freedmen's Bureau was for a portion of the state way beyond anything they had signed on to support and die for in the war. ${ }^{9}$

\section{From Colonization to Emancipation}

New Jersey was the last state north of the Mason-Dixon to provide for the abolition of slavery in 1804 at a time when many abolitionists subscribed to gradual emancipation, compensation for slaveholders, and colonization of the nation's black population outside of the United States. New Jersey's failure to embrace the Emancipation Proclamation and endorse opening the ranks of the Union army to black enlistment is a continuation of the state's conservative opposition to anything resembling the principles of antebellum militant abolitionism such as the immediate abolition of slavery, non-compensated slaveholders, and anti-colonization. The state's hostility to the more militant abolitionism of the antebellum era may well have been derived from the founding role and rigorous support given to the movement to colonize blacks in Africa by some of New Jersey's most prominent leaders. New Jersey, which had the largest black population of any free state on the eve of the Civil War, ${ }^{10}$ did not have a strong Second Great Awakening evangelical movement, which served as the spiritual foundation of the militant abolitionism of the 1830s. This circumstance contributed to a relatively weak abolitionist movement in the state.

Colonization became an attractive solution to ending the twin dilemmas of slavery and the presence of a black population many felt was racially inferior and too physically and culturally different to be absorbed into the body politic of America. The Reverend Robert Finley of Basking Ridge played an important role in the founding of the American Colonization Society and the New Jersey chapter in the winter of 1816-1817. Such national luminaries as Daniel Webster, Henry Clay, Francis Scott Key, and John Randolph attended organizing meetings held in the nation's capital. Finley's death in October 1817 left the New Jersey colonization movement somewhat rudderless. The expected increase in the free black 
population by 1825 due to the provisions of the state's 1804 gradual abolition law granting freedom to young men and women as they came of age sparked a resurgent interest in colonization. A reorganized New Jersey Colonization Society led by a distinguished former naval commander, Robert Field Stockton, a Princeton graduate and future Democratic United States Senator, attracted a following once again. Neither the New Jersey State Legislature nor the New Jersey Colonization Society favored the abolition of slavery by the national government. ${ }^{11}$ The problem for Finley and Stockton, like all advocates of the colonization panacea, was two-fold. On the one hand, there was the unalterable opposition by Southern planters to colonize their cheap labor supply outside of the country. On the other, was the fact that black Americans perceived the American Colonization Society as a slave holder conspiracy to rid the country of free black antislavery advocates, many of whom who wanted freedom in America.

The revived New Jersey Colonization Society achieved negligible success in New Jersey despite raising sufficient funds to purchase a ship, the Saluda, and 160,000 acres of land to be added to the Liberian colony founded by the national organization. Only 8,204 blacks were colonized in Liberia between 1820 and 1853, of which only 24 were from New Jersey. A number of the state's leaders of the African American community were hostile to the American Colonization Society such as Thomas D. Coxsin of Gloucester County who prepared a report to the 1832 Convention of Free People of Colour condemning the organization for coercing free blacks to emigrate to Canada. Prominent black clergyman, Samuel E. Cornish, pastor of the First Presbyterian Church in Newark, and Theodore S. Wright, a well-known Presbyterian minister from New York City, collaborated on an anti-colonization pamphlet entitled, The Colonization Scheme Considered. ${ }^{12}$ Colonization as a viable solution to America's twin problems of slavery and race failed miserably; the concept had its adherents well into the Civil War years, such as Abraham Lincoln who attempted to persuade black leaders at a White House meeting in the summer of 1862 on the efficacy of colonization. ${ }^{13}$

On the eve of the Civil War with the more pressing issues of disunion and Southern secession, the idea of colonization seemed irrelevant as a solution to sectional division. Several New Jersey governors from the pre-Civil War era, through the war years, and into Reconstruction reflected the essential conservatism of the 
state on the issues of slavery, abolition, and equality. Only William Augustus Newell, who represented the early coalescing of antiDemocratic Party forces in the mid-1850s after the collapse of the Whig Party, which would eventually become the Republican Party, and Marcus Ward who assumed the governorship of the state in the year following the end of the Civil War, appeared to comprehend the moral implications of the war, emancipation, black citizenship, and Reconstruction. They represented the progressive tendencies in New Jersey in the immediate pre- and post-Civil War eras.

George Franklin Fort was the prototype for New Jersey governors in their indifference to the inhumanity of slavery while adhering to a constitutionalist argument that recognized its legitimacy and longevity. Fort's 1850 Democratic gubernatorial campaign benefitted from Whig divisions over the Compromise of 1850. Important Whig newspapers condemned the Fugitive Slave Act part of the Compromise as fundamentally at odds with the principles of the Constitution and liberty. They linked the Democrats to the "Slave Power" who sought the unlimited expansion of slavery and promoted the popular prejudice against the state's black population. Democrats countered with charges that Whigs were seeking to make New Jersey into an abolition state. Fort asserted that the Fugitive Slave Act as congressionally passed legislation constitutionally bound the state to its enforcement. The Whig schism between those advocating an anti-immigrant nativist party and those wanting a party emphasizing anti-slavery extension led to an overwhelming Democratic victory for Fort who garnered $53.9 \%$ of the vote. This state division reflected the dissention within the national Whig Party which would lead to its national demise in less than five years. ${ }^{14}$

Fort's successor, Rodman McCamley Price, a former naval officer and ex-Democratic Congressman, was uninterested in the abolitionist campaign for more humane treatment of the nation's black inhabitants and supported the Southern territorial solution to the slavery question which allowed for unrestrained westward movement of Southern slavery. Assuming the governor's office in 1854, Price in 1856 used his control of patronage and money to keep the Democratic Party platform at the state convention favorable to local control of slavery in Kansas. Local control gave the pro-slavery faction in Kansas an opportunity, if they controlled the state's politics, to open Kansas to slavery. Price went on to direct the Stephen A. Douglas 1860 presidential campaign in the 


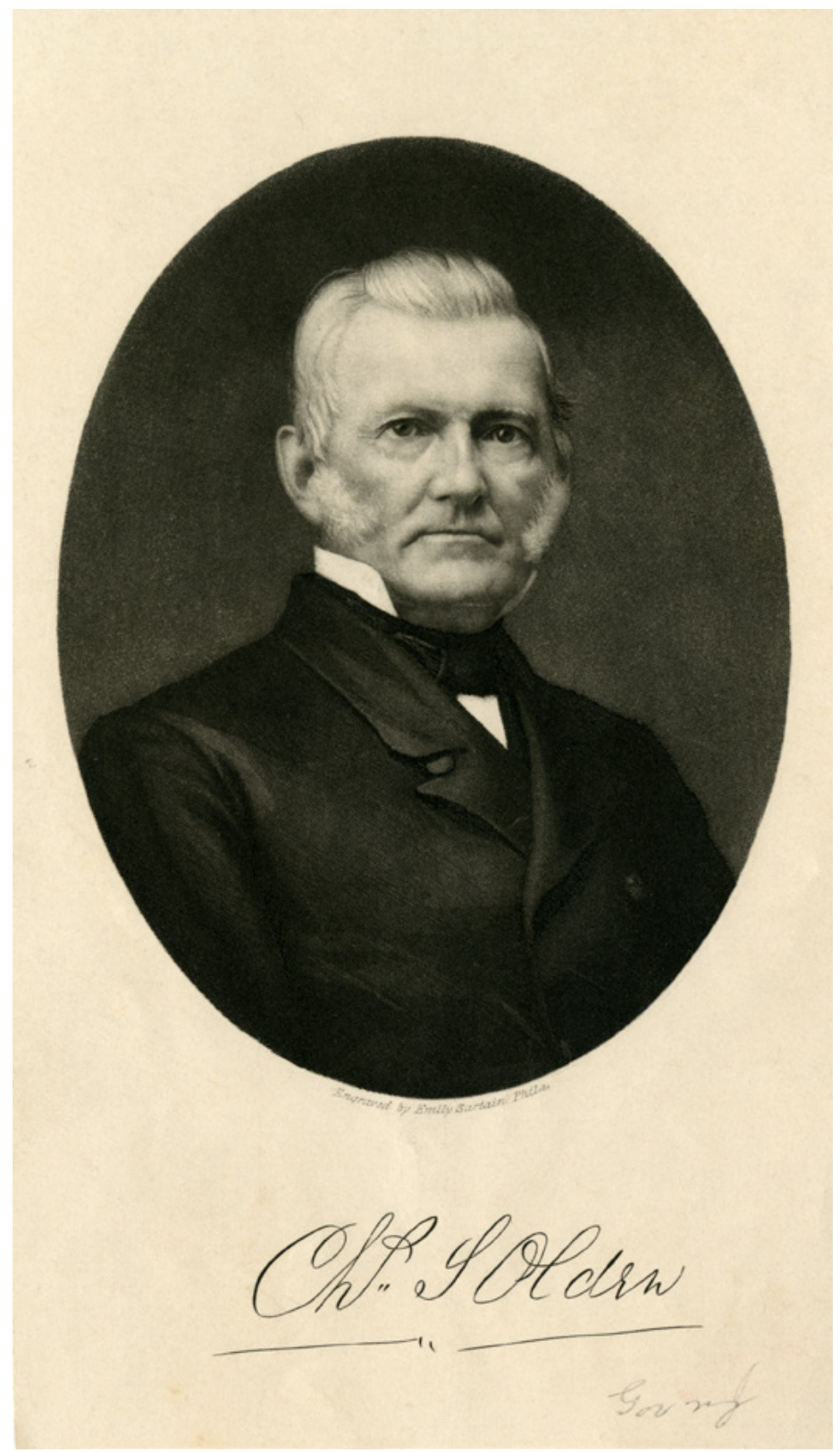

Portrait of Charles Olden engraved by Emily Sartain of Philadelphia.

Rutgers Special Collections and University Archives. 
state. Following the secession of a number of Southern states in the winter and early spring of 1861, Price wrote a letter to the Newark Evening Journal on April 4, 1861, in response to an earlier letter inquiring what should be the New Jersey position regarding the division of the nation into "two permanent confederacies." He urged New Jersey residents not to take up arms against the South for it would not be in the state's economic interest since the South was an important market for New Jersey manufacturing. If the state allied itself with the North, Europe would take the Southern market and the citizens of New Jersey would be "compelled to seek employment elsewhere, our state becoming depopulated and impoverished." Price asserted, "We believe that slavery is no sin" and quotes the Confederate Constitution: "Slavery - subordination to the superior race - is his [the black's] natural and normal condition." ${ }^{15}$ While many voters would not accept a proposed alliance with the South in the event of war, Price's economic and racist attachment to the Confederacy explains the thought and action of a significant portion of the "Peace Democrat" faction.

William A. Newell succeeded Price and took the oath of office in 1857 as the leader of a loosely and newly formed political party in New Jersey, known as the "Opposition," an anti-Democrat coalition of former Whigs, nativists from the American Party (aka "Know-Nothings"), and those associated with the newly formed national Republican Party. Aware of the conservative nature of New Jersey and the hostility to emancipation, blacks, and abolitionists, the "Opposition" was not very eager to identify with the newly formed Republican Party and its standard-bearer, John C. Fremont, in the 1856 Presidential election. Newell stood for stricter naturalization procedures, increased voting restrictions on naturalized citizens, and more restrictive voter registration laws for incorporated cities where the immigrant population was more numerous. Like Republicans of that period, he opposed the extension of slavery into the territories, but considered Northern abolitionists an equal threat to the Union. Republicans and American Party leaders agreed to run Newell as a common gubernatorial candidate at the state level. Newell moved more clearly into the Republican Party by the end of his term in 1860 and supporting Lincoln in 1860 and 1864 . He returned to the halls of Congress in 1865 and supported "Radical Reconstruction" in the South, albeit it more moderately than many. ${ }^{16}$ 
New Jersey's newly elected governor, Charles Olden, assumed the office of governor with his inauguration in January 1860. Although a Quaker and entering politics as a Whig, Olden was a conservative who opposed the extension of slavery and believed in the enforcement of the Fugitive Slave Act. ${ }^{17}$ In 1859, he received the nomination from the Opposition Party, constructed from the remains of the defunct Whig Party and the nativist American Party. As a conservative, he felt that despite the opposition of "a large portion of the citizens of the United States" to slavery, every "member [state] of the confederacy reserves to itself the exclusive independent control of its domestic policy; only the powers that are essential to the preservation of the body politic are conferred on the General government." 18 Olden's views were more conservative than those of many Republicans, yet he supported Lincoln in the 1860 election and the Crittenden Compromise to avert further secession of Southern states after South Carolina seceded in December 1860. The Crittenden Compromise would have extended the old Missouri Compromise line to the West Coast, but also held out the possibility of slavery in future territorial acquisitions by the United States. Olden viewed the secession crisis as caused "by a few persons of extreme views both North and South."19

Olden considered New Jersey to be a state moderate or conservative in its political temperament and would have had little problem with the Democratic Party motto circulating in the 1860 election: "The Constitution as it is, the nation as it was." ${ }^{20}$ Olden attended a meeting of Union governors in Altoona, Pennsylvania, in September 1862. Governor Andrew G. Curtin of Pennsylvania called the conference to urge Lincoln to pursue a more aggressive war policy and to fire General George McClellan, leader of the huge but unsuccessful Army of the Potomac. Two developments stemming from the Union victory at Antietam, Maryland, which thwarted Confederate General Robert E. Lee's first attempt to invade the North, affected the Lincoln administration's conduct of the war and the conference. The Antietam victory gave Lincoln the opportunity to issue the Preliminary Emancipation Proclamation on September 22,1862 , from a position of strength and avoid the appearance of emancipation as a desperate Union war measure to encourage slave resistance and revolt in the Confederacy. The governors adopted resolutions, one of which supported the Emancipation Proclamation. However, Governor Olden joined the governors of the four Union border slave states of Delaware, Maryland, Kentucky, 
and Missouri in refusing to sign because of their objection to the section approving the Emancipation Proclamation. ${ }^{21}$ Even though Lincoln was positioning to sell the Emancipation Proclamation to a less-than-enthusiastic Northern electorate as a war measure required by military necessity, Olden could not bring himself to support the Proclamation because of the potential political dangers of supporting such a measure in conservative New Jersey.

The New Jersey electorate reacted most negatively against the Republican Party and the Preliminary Emancipation Proclamation in the 1862 November elections rather than positively to the Union victory at Antietam, the Union's greatest military victory in the eastern theater of operations. Joel Parker, a "war Democrat," and staunch critic of the Lincoln administration easily defeated Marcus Ward by 14,394 votes with the largest majority in a gubernatorial electoral history. ${ }^{22}$ Governor Joel Parker in his inaugural address of January 20, 1863, condemned abolitionists and Lincoln's Proclamation observing New Jersey decades earlier had abolished slavery without vitriolic conflict. New Jersey is held up as a model for how emancipation should be undertaken, if at all:

If emancipation should ever come, it will come so as to be of the greatest benefit to both races. It will come, as it did in New Jersey, by the voluntary action of the people of the States where the institution exists, peacefully and gradually, and without the dictation or interference of the General Government or the governments of other States, and without calling on the other States to incur an immense debt, equivalent to a mortgage on every acre of land within their limits. ${ }^{23}$

Parker blamed the fanaticism of antebellum abolitionists for the cause of the war and Southern extremists for the "political heresy" of secession. However, he seemed to save his harshest criticism for Northern antislavery critics whom he claimed harbored a "deep rooted prejudice against Southern institutions. That the design of many was to abolish slavery in the States was evident. Politicians, to gain place and power, indulged in the most abusive epithets. The rostrum, the pulpit, and the press fanned the flames of hate." ${ }^{24}$ It was not only local politicians who engaged in this fratricidal rhetoric, but also "men high in the national councils" who approved and encouraged this divisiveness. The newly elected 


$$
8
$$


Governor believed this vehement criticism of slavery and the South "was calculated to produce, and did produce the bitterest hatred on the part of the Southern people, and they committed retaliatory acts of violence, illegal, and entirely unjustifiable." 25

Governor Parker's inaugural speech attributed moral equivalency to both the Union and Confederate causes even while the United States was at war for its very survival with the Confederacy. According to Parker, the transgressions of the Democratic Party's political opponents not only provoked Southern secession, but also threatened the Constitutional rights of free speech and the right to dissent of Northerners by misuse of presidential war powers which led to the suspension of habeas corpus and the issuance of the Emancipation Proclamation. Parker was accurate in his assertion that some New Jersey citizens "have been seized without due process of law, without the opportunity of investigation before a committing magistrate, without being confronted by accuser or witnesses, without being informed of the cause of detention; and without indictment or trial have been forcibly taken and confined as prisoners out of the State of New Jersey." 26 He does not argue that writs of habeas corpus can't be suspended, but rather that suspension of the writ is an enumerated power given only to Congress. While Lincoln's suspension has been debated by Constitutional scholars, it was Lincoln who had to deal quickly with the efforts of those whose activities subverted the Union war effort and some whose speeches and writings came perilously close to treason. The partisan contentiousness of the Civil War Congress could reduce the effectiveness of government in dealing with these issues as well as those periods in which Congress was not in session. ${ }^{27}$

The governor saw the suspension of the writ of habeas corpus as an infringement on "personal liberty," which is "one of the absolute rights of man," because it led to temporary imprisonment without trial. Yet he did not perceive slavery as an infringement on the "personal liberty" of enslaved blacks for they were property and not part of the American body politic and therefore the rights and liberties of the Constitution and the Declaration of Independence did not apply to them. For the governor, the Emancipation Proclamation was yet another misuse of the "war powers" concept by Lincoln and a violation of the property rights of Southerners: "The chief fruit of this 'war power' is the Emancipation Proclamation, which, if it be constitutional, 
at once yields to the Executive not merely legislative powers, but legislative powers beyond those which Congress can lawfully exercise." Parker turns his attention to the plight of the poor slave for whom freedom would not be beneficial and urges Northerners to examine emancipation "not only with the eye of reason, but also with the eye of humanity." He raises a question of "how the sudden liberation of three millions of beings without property, without homes, without education, industry or enterprise sufficient to provide for themselves ... is to benefit either the white or black race?"28 Parker poignantly and rhetorically asks of his inaugural audience: "Where are they to go? To colonize such a multitude, even if a place could be procured and they would be willing to emigrate, would involve the nation in irretrievable bankruptcy." 29

This question and dilemma seemed almost unsolvable for Parker. Another unworkable solution and great threat to the public peace and tranquility involved black migration northward. "Should they wander North, as many fear, and against which probability some States have already provided, they would be under the worst form of social slavery, and the burthens of taxation and debt now upon us would be so increased as seriously to embarrass remote posterity." The implications of mass black migration for the white working class and social structure did not go unnoticed by Parker and other Northern Democratic Party politicians who constantly played the "race card," even when the threats were more theoretical than actual. The governor noted: "We are told that there would be neither more nor less room for labor, and that if they should come here the white laborers can exchange places with them. Are we willing for such an exchange?" Parker never identified who exactly advocated displacing white workers with black migrants. More importantly, without explicitly stating his belief in the dysfunctional nature of multiracial societies, at least without slavery, he rhetorically raises questions about the plight of blacks in such societies: "Does any sane man believe that two distinct races of men, of different color, who cannot by any means be brought into social equality, can long exist in the same locality, in almost equal numbers, without one race becoming subject to the other?"30

Governor Parker, in his final inaugural criticism of the Emancipation Proclamation, found the Proclamation to be immoral and a threat to the safety of white Southerners. Rhetorically, he asked the audience, "Are we to violate the rules of civilized warfare by inviting and encouraging servile insurrection, 
which, after it has borne its bitter fruits of indiscriminate slaughter, must inevitably end in the extermination of the servile race? Is it humane to subject these unfortunate beings to the consequence?"31 Beyond his questionable concern and dire predictions for the plight of freedmen in a post-emancipation world, Parker's belief in a pre-Civil War idyll embodied in the slogan, "The Constitution as it is, the nation as it was," is predicated on a view of slavery as a benign institution compatible with the democratic principles of the enlightenment and justified in the exclusion of an "inferior race" from the entitlement of liberty. In the final analysis, Parker blames the abolitionists: "Abolition and Secession are the authors of our calamity, and Abolition is the parent of Secession." ${ }^{32}$

A potential solution to Parker's dilemma involved the establishment of free schools as attempted by the Freedmen's Bureau and Northern Christian missionaries sent to the South. President Andrew Johnson's veto of the bill to extend the Bureau had many Southern supporters who were also opposed to Christian missionaries establishing schools for former slaves. The major solution to the alleviation of impoverished freedmen and economic dependency involved some form of compensation or reparations for the economic exploitation of slavery through some form of land reallocation. Attempts were made by the Freedmen's Bureau to redistribute ex-Confederate abandoned lands to the freedmen in accordance with their function, but were blocked by President Andrew Johnson. A bill proposed by Pennsylvania Congressmen Thaddeus Stevens involving the confiscation and redistribution of the lands of the "chief rebels" was not passed by Congress. ${ }^{33}$ For many members of Congress and Northerners in general, the respect for the property rights of the ex-Confederate planters superseded the needs of four million poor former slaves who had demonstrated their loyalty to the Union by their enlistment in the Union army and service as spies for that army. In the end, subscription to a belief in the inherent racial superiority of whites and inferiority of blacks blocked any conception of blacks as independent and economically productive members of society capable of engaging in the democratic process.

The New Jersey Democratic State Central Committee continued the denunciation of the Emancipation Proclamation as a rejection of the congressionally authorized purpose of the war, which mandated only the suppression of the rebellion. The Central Committee blamed "abolitionist fanatics" for pressuring 
Lincoln into issuing the Proclamation which would "destroy the private property of the innocent people of those states along with the guilty." In addition, Democrats declared the Preliminary Emancipation Proclamation and the Emancipation Proclamation to take effect on January 1, 1863 unconstitutional and not justified by presidential war powers. Parker and the Democratic Party owed their November 1862 overwhelming victory to the Democratic Party's staunch opposition to the Proclamation and simultaneous cynical exploitation of and creation of public fear of black migration into Northern states allegedly following emancipation. They turned narrow Democratic majorities in the state legislature into significant ones from forty-five to seventeen in the New Jersey assembly and to twelve to eight in the state senate. ${ }^{34}$

According to Congressman Nehemiah Perry in 1862, Lincoln's illegal preliminary emancipation imperiled the Constitution and the United States. Perry never adequately explains how emancipation as a military measure to win the war would contribute to the destruction of the Union. Perry asserts the purpose of the war remains the "preservation of the country" not its destruction by annihilation of "the great institution of the South," black slavery. ${ }^{35}$ Perry reflects the state's conservative strict construction of the Constitution, traditional hostility to blacks, and devotion to property rights all of which blinded them to the military benefits of emancipation and exaggerated the dangers of such a course. The Newark Journal explained the irrational concern of a portion of the state's residents over Confederate rights and liberties in ways which demonstrated that racial solidarity superseded military necessity to bring the war to a successful conclusion: "After we have sent our sons and brothers to the field to aid in the restoration of the Constitutional Union, they are to be made instruments of the most barbarous and savage crusade against their white brethren of the SOUTH ever inaugurated in the history of mankind." ${ }^{36}$ Perry and other critics of the war continued to see their Confederate enemies as their "white brethren" while blacks are viewed as a naturally servile caste or racial outsiders incapable of assimilation into the body politic of the nation.

Two months after the Emancipation Proclamation and Governor Joel Parker's inauguration, the New Jersey legislature in March 1863, passed the infamous "Peace Resolutions" signed by a Democratic Governor and supported by Democratic majorities in the legislature. After much negotiation between the "Peace" 
and "War" wings of the Democratic Party over the wording of the resolutions amidst Republican condemnations, the "Peace Resolutions" were passed denying Lincoln's power to emancipate slaves and urged Lincoln to dispatch emissaries to the Confederacy to negotiate an end to hostilities "consistent with the honor and dignity of the national government." ${ }^{37}$ Governor Parker and the Democratic Party controlled legislature were willing to sacrifice emancipation if it would mean the end of the Civil War and possible reunification of the country. For many in New Jersey, the new 1863 addition of emancipation to the Union cause was a perversion of the war's acceptable goal of preservation of the Union. Not all in New Jersey found the "Peace Resolutions" justifiable and some as in the state's military contingent found it treasonous. Officers from the 11th Regiment of New Jersey volunteers denounced those "we regard as traitors alike the foe in arms and the secret enemies of our government who at home foment disaffection and strive to destroy confidence in our legally chosen rulers." They asserted the army was not "demoralized and clamorous for peace on any terms" as "the lying utterances of traitorous tongues." ${ }^{\prime 3}$

Northern divisions over Lincoln's Emancipation Proclamation were not only divisions over Constitutional interpretation of presidential use of "war powers" to emancipate, but also represent a chasm over the continued existence of America as a multiracial country and especially a black presence in Northern states. These lines were blurred with the passage of time and reaction to the developments of the war. Issues and positions are often inaccurately homogenized. Support for the war and preservation of the Union did not automatically lead the populace to oppose the institution of slavery. To be against slavery did not necessarily translate into support for Lincoln's Emancipation Proclamation. Support for emancipation did not always translate into a belief in racial egalitarianism or the rejection of racism. Minus the war issue of the 1860s, these were old debates of the antebellum era which the war only made more immediate and intense. It was Lincoln who had to deal with the ramifications of his decision to issue the Preliminary and final Emancipation Proclamations and the very real political backlash of a public already disappointed with the course of the conflict and the Union failure to bring about a quick end to the war and the Confederacy. 
In its exploration of the sixteenth president of the United States, the recent Hollywood movie Lincoln-although superior to many of its cinematic predecessors-fails to examine the conundrum Lincoln faced in issuing the Preliminary and final Emancipation Proclamations even prior to his quest for a Thirteenth Constitutional Amendment to end slavery. Lincoln would issue the Preliminary Proclamation despite the knowledge that it might hurt him and his party at the polls in the 1862 November election and perhaps undermine the Union war effort that it was designed to help. In the case of New Jersey, it hurt Lincoln and his party while contributing to Joel Parker's victory in the gubernatorial race. Lincoln harnessed his political fate, the party, and that of the nation to emancipation, but what of the prospect of a nation without slavery? Lincoln, like his political hero the late Senator Henry Clay from Kentucky, always conceived of emancipation tied to colonization of the black population in Africa, the Caribbean, or Central America.

In the emancipation/colonization model that Lincoln and Clay supported, their antislavery beliefs were closer to those of eighteenth-century abolitionists than the nineteenth-century antebellum antislavery movement. By the 1830s and 1840s, most of the leading white abolitionists had rejected colonization along with gradualism and slaveholder compensation following the lead of William Lloyd Garrison in his 1832 anti-colonization publication, Thoughts on African Colonization. Lincoln had been a member of the Illinois Colonization Society and addressed the organization in 1853 and 1855 . It is interesting to note that Illinois conventions of black residents denounced colonization in 1853, and yearly between 1856 and $1858 .{ }^{39}$ Nevertheless, Lincoln held fast to his ideas on colonization as a solution to both slavery and America's black population. Lincoln's lack of pre-Civil War involvement with the Midwestern abolitionist movement and interaction with African Americans may have contributed to his mistaken notion of colonization as an answer to America's racial dilemma and belief in the existence of African American support for colonization. ${ }^{40}$ Lincoln held two meetings in the summer of 1862 to promote emancipation and colonization for the four Union border slave states and to encourage the African American population to consider colonization. He believed colonization would make emancipation more acceptable to the border slave states and the encouragement of African American colonization would make 
a presidential emancipation edict more acceptable in Northern states where Democratic parties were exploiting fears of a postemancipation black influx.

On July 12, 1862, two dozen Congressmen met with Lincoln at the White House to discuss the president's proposal for emancipation. The majority of them rejected his proposals involving gradual emancipation, compensation for slaveholders, and colonization of the emancipated black population. Before his next meeting with black leaders at the White House the following month, draft resolutions were read at a cabinet meeting on July 22 of what would become Lincoln's Preliminary Emancipation Proclamation giving the Confederate States of America the option to end their secession, return to the Union, and retain slavery by January 1, 1863 or have slavery declared abolished in their states. Secretary of State William Henry Seward persuaded Lincoln to wait for a Union victory before issuing the Proclamation lest some would view it as an act of desperation. Lincoln, in fact, had been considering issuing such a Proclamation even before his meeting with border state congressmen. He met with African American leaders at the White House on August 14, 1862 explaining that they suffered in the United States and that America suffered by their presence, and pushed colonization as a solution. This did not go over well with those black leaders present and in the coverage by black newspapers which denounced the meeting and colonization. Six days after that meeting, Horace Greely, an advocate for emancipation, wrote an open letter published in the New York Tribune to the public and aimed at the president entitled the "Prayer of Twenty Millions," which was a call in absentia for four million enslaved, their sympathizers, and supporters of the Union cause for the enforcement of the Second Confiscation Act passed by Congress that summer which would have allowed for the confiscation of both material and human property of the rebels. The president's reply printed in a rival newspaper was his classic response: "My paramount object in this struggle is to save the Union, and is not to either save or destroy slavery. If I could save the Union with freeing any slaves I would do it, and if I could save it by freeing all the slaves I would do it." 41

Lincoln's views on race, slavery, emancipation, and colonization were in a state of flux. At the very time of his White House meetings in the summer of 1862 and the public correspondence with Greely, he knew that he was going to issue 
the Preliminary Emancipation Proclamation. He also knew that it was highly unlikely that any Southern state would have taken his offer to return to the Union considering the still favorable military position of the Confederacy. It is logical to view this chronological trail of events as Lincoln preparing a skeptical public for the final Emancipation Proclamation of New Year's Day, 1863, and the defense of emancipation as a military necessity. While this is quite plausible and probably accurate, it also ignores that Lincoln was still ambivalent about a multiracial America and had not given up on colonization. Lincoln signed a contract on December 31, 1862 for black American colonization on Cow Island, off the coast of Haiti, and sent a letter to a number of countries in Central America inquiring as to their interest in black American colonization. ${ }^{42}$ The ultimate failure of these efforts in 1863 marked the end of the government's efforts at colonization and set the stage for the creation of a new multiracial republic without slavery. Lincoln may have realized that with the Emancipation Proclamation's authorization of black enlistment in the army and black contributions to the war, African Americans would reject colonization and even more rigorously claim a right to citizenship.

In 1864, Lincoln withstood pressure from Democrats and even conservatives within his own party to drop emancipation as a condition for restoration of the Union through a negotiated peace. Horace Greely even urged Lincoln to send emissaries to a Peace Conference at Niagara Falls to meet with Confederate representatives. The conference failed and Confederates released a letter from Lincoln, "To Whom It May Concern," making it clear that he would not consider any restoration of the Union that failed to include the complete abolition of slavery. The letter sparked a flood of denunciations from Democrats and a few conservative Republicans urged him to withdraw the condition. ${ }^{43}$ Democrats and conservative Republicans feared Emancipation would cost the nation an opportunity to negotiate an end to this most costly of all wars and Democrats perceived a golden opportunity to make political gains.

Democrats in New Jersey, like their national counterparts, would intensify their vitriolic attacks in editorials and speeches upon Lincoln and the Republican Party even a year before the 1864 presidential election. A month after the Emancipation Proclamation, Democratic Assemblyman John B. Perry introduced a bill on February 4, 1863, into the New Jersey legislature, entitled 
"An Act to prevent the immigration of negroes and to define the standing of the negro race in the State of New Jersey." The bill defined as a "negro" any person with "one- fourth Negro blood" and made interracial marriage illegal in the state. ${ }^{44}$ The bill died in the House Judiciary Committee chaired by Jacob Vanatta, a Morris County Democrat, who would soon introduce his own "negro" exclusion bill (A-212) on March 5, 1863 entitled "An Act to Prevent the Immigration of Negroes and Mulattoes." The bill revived the colonization ideal, at least in the state, by providing that blacks entering the state would be transported to Liberia or the West Indies. The bill passed the assembly, but died in the senate. From January 1862 through March 1863, twenty-four petitions for black exclusion were submitted to the state government. Twenty-one came from counties with more than 1,200 blacks. ${ }^{45}$ David Naar, editor of the vehemently anti-Lincoln Trenton True American, observed: "As long as Abolitionism rules the country, negroes must be let loose, and when they are let loose, they must be fed, clothed, nursed and housed, for the most part at the white man's expense." 46 Naar had made a practice of reprinting distorted articles from the New York World labeling interracial Republican social/political events as "miscegenations balls." 47

The Trenton True American attributed the demise of the bill to the expense of deportation. The Newark Daily Advertiser attributed the bill's failure to doubts about its constitutionality even among supporters. The New Jersey black population of some 25,000 was nearly twice that of any other free state in 1860 and contributed to the fears of black inundation and subsequent fears of miscegenation. ${ }^{48}$ Winthrop Jordan observed in his classic study of American racial attitudes, White Over Black: "One of the most interesting and revealing aspects of American attitudes was the nearly universal belief that emancipation of Negroes from slavery would inevitably lead to increased racial intermixture." 49 The national Democratic Party made a concerted effort during the Civil War to continue the anti-abolitionist rhetoric, circulating in the Northern states during the Jacksonian era and carried forth through the 1840s and 1850s into the Civil War years. They charged abolitionists and later the Republican Party with advocating racial equality and "racial amalgamation." Stephen A. Douglas, in his 1858 debates with Lincoln for the United States Senate, referred to the Republican Party repeatedly as the "Black Republicans" implying a party dominated by abolitionists, influenced by blacks, 
and supporters of racial equality. ${ }^{50}$ As early as 1860 , the Democratic National Executive Committee circulated a pamphlet accusing Lincoln of advocating complete political and social equality between the races. The Committee rhetorically asked: "Is your equal entitled to vote, hold office, sit at the same table with you, and marry your daughter?" 51

Fears of massive black migration into New Jersey from newly emancipated slaves threatening the economic well-being, political stability, and social fabric of the state were synthesized into a conspiracy threatening the racial purity of the state's population. In December 1863, an anonymously published booklet by David Croly and George Wakeman, two New York newspaper reporters, entitled "Miscegenation: The Theory of The Blending of the Races, Applied to the American White Man and Negro" was just such a conspiracy synthesis. Their plan was to send a copy of the booklet with unsigned requests to famous abolitionists and Republicans for sympathetic responses. They planned to circulate these responses in the Democratic press. ${ }^{52}$ David Naar, editor of the vehemently antiLincoln Trenton True American, pushed his theory of an abolitionist amalgamation conspiracy in an editorial on the booklet: "Such is the last phase of abolitionism, for let it not be imagined that the author of this pamphlet is alone in his views." ${ }^{\prime 53}$ Apparently, some in the New Jersey General Assembly took "Miscegenation" seriously as they passed a bill 51-0, "An Act to Prevent the Admixture of the Races" in March 1864, introduced by Assemblyman Thomas Dunn English. The senate failed to act on the bill and it never became law. ${ }^{54}$

Despite the resort to racist appeals and a willingness to discard the Emancipation Proclamation, the Democratic presidential candidate and former Union General of the Army of the Potomac, George B. McClellan lost every Northern state except New Jersey, Delaware, and Kentucky. Racist propaganda could not overcome nor obscure a series of ultimately war ending Union victories in 1864 prior to the election by Admiral David Farragut in Mobile Bay, General Sherman's capture of Atlanta on September 2, 1864, and General Sheridan's sweep of Confederates from the Shenandoah Valley. ${ }^{55}$ Northern public opinion saw the light at the end of the tunnel and the conclusion to the long "struggle without end," the most deadly of all American wars. Lincoln, who had grave doubts in the spring of 1864 about his own re-election, as did some in his own party who desired his replacement, now stood vindicated by Union victories upon the battlefield. 


\section{Memories of War: Reconstruction and Reconciliation}

In Steven Spielberg's Lincoln, the newly re-elected Lincoln in 1865 battles a lame duck Congress to pass the proposed Thirteenth Amendment to the Constitution abolishing slavery and enshrining the Emancipation Proclamation in the Constitution safe from opponents who valued the property rights of former Confederate enemies more than the human rights of blacks. Spielberg's movie is an excellent corrective to the simplistic view of a homogeneous North in total support of emancipation and the Civil War amendments. This view was long ago rejected by historians and for far too long was promulgated in public consciousness by years of simplistic movies, books, and secondary school curricula. It is unfortunate to note that the New Jersey legislature at various times rejected all three Civil War amendments. The Thirteenth Amendment was rejected by the Democratic Party-controlled New Jersey legislature and only ratified after it had already become part of the Constitution by Republican majorities in the legislature and supported by the newly inaugurated Republican Governor, Marcus Ward. He announced in his January 1866 inaugural speech that the insulting failure to ratify the amendment constituted an embarrassment "to the honor of our state and people." Ward and his colleagues in the legislature also secured New Jersey's ratification of the Fourteenth Amendment granting citizenship to the freedmen only to have it rescinded when the Democratic Party returned to power in the state legislature. A sense of déjà vu emerges when the Democrat-controlled legislature rejected the Fifteenth Amendment, granting voting rights to blacks, and a subsequent Republican legislature passed it. ${ }^{56}$

New Jersey Civil War and Reconstruction era governors, Joel Parker and Marcus Ward, symbolize not only New Jersey divisions, but also the regional and national fractures over slavery, emancipation, race, and the future place of the freedmen in American society. For Marcus Ward, liberty was universal and not limited by the right of a state to restrict its universality: "Human slavery has been extinguished and prohibited forever, and the millions of [the] race who have drank its bitter cup, now drink the pure water of Liberty. No longer may one man hold another in bondage, but all are held equal under the law, entitled to equal protection, and alike permitted to enjoy life, liberty, and happiness." 57 Marcus Ward's inaugural address foreshadowed the themes of "universal liberty" and "freedom national" expressed 
so eloquently nearly two months later in Lincoln's more famous Second Inaugural Address and his last public address on April 11, 1865 contemplating voting rights for the Union's black soldiers and educated classes.

Parker's January 16, 1872 inaugural was a defense of counter-reconstruction or "redemption" mounted by Southern Democrats and even the Klan who essentially rejected the Civil War Constitutional Amendments embodying the idea of citizenship and voting rights for the freedmen. He denied the constitutionality of the Ku Klux Klan and Force Acts passed to guarantee black political rights free from the violence of white supremacist paramilitary organizations: "Nor is it an excuse for violating the constitution, that crime has been committed. That there have been acts of lawlessness and disorder in portions of the South cannot be doubted. That the perpetrators of these crimes have, in some cases, been incited to deeds of violence by bad governments, or in retaliation for wrongs, is no justification." Parker asserted these crimes of political violence were due to "bad government, or in retaliation for wrongs" and implied they were committed by "biracial Republican coalitions state governments." While stating there can be "no justification" for this violence, he actually provides a partial defense for these actions by refusing to admit that the violence was part of an organized attempt to intimidate African American and white Republican voters. His suggestion that those responsible "should be arraigned tried and punished in the proper legal tribunals" is disingenuous considering the reconstituted Southern Democratic Party was the political beneficiary from this violence and showed very little interest in bringing these elements to trial with whom they were often affiliated. Parker's inaugural address condemned Congressional Reconstruction and made a plea for Southern white amnesty. ${ }^{58}$

Parker epitomized the view that Congressional

Reconstruction was a mistaken policy and in so doing reflects the "reconciliationist" memory of the war enunciated by historians and public remembrances of the Civil War emerging in the nineteenth century, but achieving dominance in the early twentieth century. David Blight in his superb study, Race and Reunion: The Civil War in American Memory identified three visions of Civil War memory: (1) a "reconciliationist" vision uniting both sections attributing noble motives and "moral equivalency" to both sides while extolling the valor and courage of soldiers on both sides; (2) a "white 
supremacist vision" which justified violence and terror and "locked arms with reconciliationists of many kinds, and by the turn of the century delivered the country a segregated memory of the Civil War on Southern terms;" (3) an "emancipationist vision" which was "embodied in African Americans' complex remembrances of their own freedom" and in the "politics of radical Reconstruction." Blight astutely notes the "forces of reconciliation overwhelmed the emancipationist vision in the national culture." It is the historical narrative of "how the inexorable drive for reunion both used and trumped race." The triumph of sectional reunion and the "reconciliationist" vision "could not have been achieved without the resubjugation of many of those people whom the war had freed from centuries of bondage." 59

American memory for many transforms Lincoln from the "Great Emancipator" of 1863 who is intent on having the Constitution safeguard the work of the Emancipation Proclamation to Lincoln the great conciliator. Lincoln's Second Inaugural Address is remembered more for the last paragraph of "reconciliationist" rhetoric: "With malice toward none, with charity for all, with firmness in the right as God gives us to see the right, let us strive on to finish the work we are in, to bind up the nation's wounds." A lesser known and quoted passage of the address essentially denies the concept of "moral equivalency" between the two sides fighting over the cause of the war he identifies as slavery: "It may seem strange that any men should dare to ask a just God's assistance in wringing their bread from the sweat of other men's faces, but let us not judge not, that we be not judged." However, Lincoln proceeds to, in fact, judge when he suggests the continuing carnage of a war seemingly without end was the price to be paid or penance for the toleration of slavery: "Yet, if God wills that it continue until all the wealth piled by the bondsman's two hundred and fifty years of unrequited toil shall be sunk, and until every drop of blood drawn with the lash shall be paid by another drawn with the sword, as was said three thousand years ago, so still it must be said 'the judgments of the Lord are true and righteous altogether."'60

The recent Oscar winner for Best Motion Picture, 12 Years a Slave presents an "emancipationist vision" of slavery and one consistent with historical revisionism on the South's "peculiar institution" that commenced in the post-World War II era.

Spielberg's Lincoln revives the "emancipationist vision" of Lincoln of the Civil War, immediate postwar years, and revisionist history 
beginning in the 1960s. The prototype of Hollywood's gradual and evolving commitment to the emancipationist and revisionist history of this period was Glory (1989), a Civil War film about the African American 54th Massachusetts Regiment and the storming of the Confederate stronghold Fort Wagner in South Carolina. Recently, Hollywood has contributed significantly to educating the public and placing before the public cinematic representations that are more consistent with the scholarship and interpretations of Civil War historians. Hollywood has initiated a corrective to the approximately 500 silent era movies about the Civil War portraying slavery from the "moonlight and magnolias school" to the war from the "reconciliationst" model encapsulated in the cinematic but historically distortive masterpiece, Birth of a Nation (1915). ${ }^{61}$ One can only hope that in the future, Hollywood will turn the camera's lens to the complexities of the North in the antebellum, Civil War, and Reconstruction eras for as New Jersey's own history demonstrates - the diversity and complexity of attitudes over slavery, race, emancipation, and the Civil War are plentiful.

\section{Notes}

1. Eric Foner, The Fiery Trial: Abraham Lincoln and American Slavery (New York: W.W. Norton, 2010); Doris Kearns Goodwin, Team of Rivals: The Political Genius of Abraham Lincoln (New York: Simon and Schuster, 2006); Merril D. Peterson, Lincoln in American Memory (New York: Oxford University Press, 1994); David Donald, Lincoln (New York: Simon and Schuster, 1995);Guy Gugliotta, "New Estimates Raises Civil War Death Too," New York Times, April 3, 2004.

2. Marlow Stern, “Tavis Smiley on Quentin Tarantino's Django Unchained," The Daily Beast (January 4, 2013), 4. http://www. newsweek.com/tavis-smiley-quentin-tarantinos-djangounchained-63111.

3. Ibid., 5 .

4. Larry A. Greene, "The Emancipation Proclamation in New Jersey and the Paranoid Style," New Jersey History 91 (Summer 1973); Forrest G. Wood, Black Scare: The Racist Response to Emancipation and Reconstruction (Berkeley: University of California Press, 1968); Sidney Kaplan, "The Miscegenation Issue in the Election of 1864," Journal of Negro History 34 (July 1949). 
5. Frank Rich, "Torture Compromise Revenge," New York, (February 11, 2013), 16-21.

6. Abraham Lincoln, "The Last Public Address," April 11, 1865, in Roy P. Basler (ed.), The Collected Works of Abraham Lincoln, (New Brunswick, NJ: Rutgers University Press, 1953), vol. 8, 399-405; James Oakes, The Radical and the Republican: Frederick Douglass, Abraham Lincoln, and the Triumph of Antislavery Politics (New York: W.W. Norton and Company, 2007), 173-245; Foner, The Fiery Trial,217-245; Paul Kendrick and Stephen Kendrick, Douglass and Lincoln (New York: Walker and Company, 2008), 233-234.

7. For detailed studies of political violence during Reconstruction see: Allen W. Trelease, White Terror: The Ku Klux Klan Conspiracy and Southern Reconstruction (New York: Harper and Row, 1971); J. Michael Martinez, Carpetbaggers, Cavalry, and the Ku Klux Klan (Plymouth, United Kingdom: Rowman and Littlefield Publishers, 2007); Douglas R. Egerton, The Wars of Reconstruction: The Brief Violent History of America's Most Progressive Era (New York: Bloomsbury Press, 2014).

8. Foner, The Fiery Trial, 3-32, 326-336.

9. Larry A. Greene, "Civil War and Reconstruction: State and Nation Divided," in Maxine N. Lurie and Richard Veit (eds.), New Jersey: A History of the Garden State (New Brunswick, NJ: Rutgers University Press, 2012), 159-166.

10. The black population in New Jersey had increased to 25,336 out of a total population of 646,699 and was proportionally twice the size of the free black population in any other free state. See: L.A. Greene, "A History of Afro-Americans in New Jersey," The Journal of the Rutgers University Libraries LVI (June 1994): 20-23; Peter O. Wacker, "The Changing Geography of the Black Population of New Jersey: A Preliminary View," Proceedings of the Association of American Geographers 3 (1971):174; Jos. C. G. Kennedy, Superintendent, Preliminary Report of the Eighth Census, 1860 (Washington, D.C., 1860), 271.

11. Douglas P. Seaton, "Colonizers and Reluctant Colonists: The New Jersey Colonization Society and the Black Community, 1813-1848," New Jersey History 96 (1978): 7, 9-11.

12. Seaton, "Colonizers and Reluctant Colonists," 13-15; Theodore S. Wright, The Colonization Scheme Considered in its Rejection by the Colored People (Newark, 1840), 4-26; Benjamin Quarles, Black Abolitionists (New York: Oxford University Press, 1969), chapter one.

13. Eric Foner, The Fiery Trial, 51, 162, 127-129, 184-186, 239-240; Benjamin Quarles, Lincoln and the Negro (New York: Oxford University Press, 1962), 113-117. 
14. Philip C. Davis, "George Franklin Fort," in Paul A. Stellhorn and Michael J. Birkner (eds.), The Governors of New Jersey, 1664-1974 (Trenton, NJ: New Jersey Historical Commission), 118-119.

15. Newark Journal, April 4, 1961; Charles Merriam Knapp, New Jersey Politics during the Period of the Civil War and Reconstruction (Geneva, NY: W.F. Humphrey, 1924), 53-54; Greene, "Civil War and Reconstruction," 159; Joel Schwarz, "Rodman McCamley Price," in Paul A. Stellhorn and Michael J. Birkner (eds.), The Governors of New Jersey, 1664-1974, 125.

16. Douglas V. Shaw, "William Augustus Newell," in Paul Stellhorn and Michael J. Birkner (eds.), The Governors of New Jersey, 1664-1974, 127, 128; See also: Knapp, New Jersey Politics during the Period of the Civil War and Reconstruction; Herman K. Platt (ed.), Charles Perrin Smith: New Jersey Political Reminiscences, 1828-1882 (New Brunswick, NJ: Rutgers University Press, 1965).

17. William C. Wright, "Charles Smith Olden, " in Paul A. Stellhorn and Michael J. Birkner (eds.), The Governors of New Jersey, 1664-1974 (Trenton, NJ: New Jersey Historical Commission), 129.

18. Proceedings Attending the Inauguration of Hon. Charles S. Olden, as Governor of New Jersey (Trenton: Printed at the "True American" Office, 1860.

19. William Gillette, Jersey Blue: Civil War Politics in New Jersey, 18541865 (New Brunswick, NJ: Rutgers University Press, 1995), 30-36; William J. Jackson, New Jerseyans in the Civil War: For Union and Liberty (New Brunswick, NJ: Rutgers University Press, 2000), 30; The "Crittenden Compromise" proposed by Senator John J. Crittenden of Kentucky involved a Constitutional amendment extending the Missouri Compromise line of 1820 , which allowed slavery south of the $36^{\prime} 30^{\prime \prime}$ and disallowed it north of that line, to the west coast. In addition, the Crittenden Compromise would federally reimburse masters for fugitive slaves and disallow any future Constitutional amendment interfering with slavery in any state. See for more detail, Francis Butler Simkins, A History of the South (New York: Alfred A. Knopf, 1963), 194, 196, 209, 212.

20. Richard P. McCormick, The History of Voting in New Jersey (New Brunswick ,NJ: 1953), 144; Richard P. McCormick, "The Emancipation Proclamation: New Jersey's Reaction," (paper presented at the Second Annual American History Workshop of the N.J. Civil War Centennial Commission, New Brunswick, NJ., December 8, 1962), 9.

21. Wright, "Charles Smith Olden," 130-132; Ironically, Lincoln soon after Antietam replaced General George McClellan because of his failure to pursue a retreating Robert E. Lee and complete the defeat 
and destruction of the Army of Northern Virginia which would have possibly ended the Civil War.

22. William C. Wright, "Joel Parker," in Paul A. Stellhorn and Michael Birkner (eds.), The Governors of New Jersey, 1664-1974 (Trenton, NJ: New Jersey Historical Commission, 1982), 132

23. Inaugural Address of Joel Parker Delivered at Trenton . . . January 20th, 1863 (Trenton: Printed by D. Naar, 1863), 14.

24. Ibid., 7, 14.

25. Ibid., 9 .

26. Ibid., 10 .

27. Inaugural Address of Joel Parker, 11, 12; For a discussion of Lincoln's suspension of the writ of habeas corpus see: David Herbert Donald, Lincoln, 303-305; Mark Neely, Jr., The Fate of Liberty: Abraham Lincoln and Civil Liberties (New York: Oxford University Press, 1991).

28. Inaugural Address of Joel Parker, 13.

29. Ibid.

30. Ibid.

31. Ibid.

32. Ibid.

33. Fawn Brodie, Thaddeus Stevens: Scourge of the South (New York: W. W. Norton and Company, 1959), 303-306; William S. McFeely, Yankee Stepfather: General O.O. Howard and the Freedmen (New York: W. W. Norton and Company, 1968), 111-116, 133.

34. Address of the New Jersey Democratic State Central Committee to the Voters of the State (October 1862), (pamphlet in Special Collections and University Archives, Rutgers University Library-New Brunswick, NJ); Jackson, New Jerseyans in the Civil War, 109; James M.

McPherson, Ordeal by Fire: The Civil War and Reconstruction (New York: Alfred A. Knopf, 1982), 296.

35. Trenton Daily True American, October 27 and November 21, 1862; Nehemiah Perry, The Constitution and the Union, Let Them Together Be Maintained (Speech delivered in the United States House of Representatives, March 6, 1862), 1, 4.

36. Newark Daily Journal, September 23, 29, 1862.

37. Gillette, Jersey Blue, 219.

38. Quoted in "The Union Is the Only Guarantee: Soldiers Protest the Peace Resolutions (1863)," in Howard L. Green, ed., Words That Make New Jersey (New Brunswick, NJ: Rutgers University Press, 1995), 147, 148. 
39. Foner, The Fiery Trial, 122-128.

40. William Lee Miller, President Lincoln: The Duty of a Statesman (New York: Alfred A. Knopf, 2008), 295-297; Foner, The Fiery Trial, 128131.

41. Quote in Miller, President Lincoln, 150, 151; Foner, The Fiery Trial, 212-229.

42. Benjamin Quarles, "The Emancipation Proclamation: A Centenary Appraisal" (paper presented at the Second Annual American History Workshop of the N.J. Civil War Centennial Commission, New Brunswick, N.J. December 8, 1962), 2; Ibid., Lincoln and the Negro, 111-117; Foner, The Fiery Trial, 229.

43. James Oakes, Freedom National, 473, 474.

44. New Jersey, "Petition," in Minutes of . . . the Eighty-Sixth General Assembly (Trenton, 1862); New Jersey, Petitions," in Minutes of . . . the Eighty-Seventh General Assembly (Trenton, 1863); Carl Hatch, "Negro Migration and New Jersey-1863," New Jersey History 87 (Winter 1969): 237, 238.

45. New Jersey, Minutes of . . . the Eighty-Seventh General Assembly, 277, 363, 364; New jersey, Minutes of . . . the Eighty-eighth General Assembly, (Trenton, 1864), 379, 380; Hatch, "Negro Migration and New Jersey," 241.

46. Trenton True American, January 13, 1863.

47. Trenton True American, September 24, 1864.

48. Trenton True American, March 26, 1863; Newark Daily Advertiser, February 27, March 26, 1863; Jos. C.G. Kennedy, Superintendent, Preliminary Report of the Eighth Census, 1860 (Washington, D.C. 1862), 271.

49. Winthrop Jordan, White Over Black: American Attitudes Toward the Negro, 1550-1812 (Chapel Hill: University of North Carolina Press, 1968), 542.

50. Basler, The Collected Works of Abraham Lincoln, vol. 3: 8-10, 16, 19, $83,145,146,315$.

51. Democratic National Committee, "The Great Issue," 4, 12-15;

Wood, Black Scare, 19.

52. Wood, Black Scare, 51-54.

53. Trenton True American, March 15, 1864.

54. Minutes of . . the Eighty-Eighth General Assembly, 533.

55. Greene, "Civil War and Reconstruction," 165. 
56. Ibid. 166, 167; Greene, "A History of Afro-Americans in New Jersey," 32, 33; Inauguration of His Excellency Marcus L. Ward, Governor of New Jersey, 12, 13.

57. Inauguration of His Excellency Marcus L. Ward, 11, 12.

58. Inauguration of His Excellency, Joel Parker, Governor of New Jersey, January 16, 1872, 15-17.

59. David W. Blight, Race and Reunion: the Civil War in American Memory (Cambridge, MA: Harvard University Press, 2001), 2, 3; See also Peterson, Lincoln in American Memory.

60. Abraham Lincoln, Second Inaugural Address, March 4, 1865.

61. Some excellent studies of Civil War films are: Bruce Chadwick, The Reel Civil War: Mythmaking in American Film (New York: Alfred A. Knopf, 2001), 7; Gary W. Gallagher, Causes Won, Lost, and Forgotten: How Hollywood and Popular Art Shape What We Know About the War (Chapel Hill: University of North Carolina Press, 2008). Melvin Stokes, D.W. Griffith's Birth of a Nation: A History of 'The Most Controversial Motion Picture of All Time" (New York: Oxford University Press, 2007); Robert Brent Toplin, "12 Years a Slave Examines the Old South's Heart of Darkness," Perspectives on History (January, 2014), 39, 40. 